\title{
Formulation and evaluation of taste mask pellets of granisetron hydrochloride as oro dispersible tablet
}

\author{
Nilesh Choudhary, Jasmine Avari* \\ Department of Pharmaceutical Sciences, R. T. M. Nagpur University, Mahatma Jyotiba Fule Educational Campus, \\ Nagpur, India
}

\begin{abstract}
Orally disintegrating systems have carved a niche amongst the oral drug delivery systems due to the highest compliance of the patients, especially the geriatrics and pediatrics. In addition, patients suffering from dysphagia, motion sickness, repeated emesis and mental disorders prefer these medications because they cannot swallow large quantity of water. Further, drugs exhibiting satisfactory absorption from the oral mucosa or intended for immediate pharmacological action can be advantageously formulated in these dosage forms. However, the requirements of formulating these dosage forms with mechanical strength sufficient to withstand the rigors of handling and capable of disintegrating within a few seconds on contact with saliva are inextricable. The purpose of this research was to mask the bitter taste of granisetron hydrochloride. To mask the taste Kollicoat ${ }^{\circledR}$ Smartseal 30D was used as coating polymer for pellet coating. The coated pellets of the drug was directly compressed with different superdisintegrant as AC-Di-Sol, Explotab and Kollidon CL in different concentration 5.0-7.5\% w/w into an ODT. The prepared tablets were evaluated for hardness, friability, weight variation, wetting time, wet absorption ratio, in-vitro disintegration time and in vitro dissolution studies. Tablets exhibited quick disintegration characteristics with Kollidon CL in concentration 7.5\% w/w i.e., within 20 seconds, which is characteristic of orally disintegrating dosage forms. More than $98 \%$ of drug was released from the formulations within 15 minutes. Formulations subjected to stability testing as per the ICH guidelines for 3 months, indicated stability with no change in taste, hardness, drug content, disintegration time and dissolution profiles. Thus, the results conclusively demonstrated successful masking of taste and rapid disintegration of the formulated dosage forms in the oral cavity.
\end{abstract}

Uniterms: Granisetron hydrochloride/taste masking. Oro Dispersible Tablet (ODT). Pellets/coating. Oral drugs/delivery system.

Sistemas de desintegração oral têm um nicho entre os sistemas de administração de medicamentos por via oral devido à maior aceitação dos pacientes, especialmente os de geriatria e pediatria. Além disso, pacientes que sofrem de disfagia, enjoo de movimento, emese repetida e distúrbios mentais preferem estes medicamentos porque não podem engolir grande quantidade de água. Além disso, os fármacos que exibem absorção satisfatória a partir da mucosa oral ou que se destinam a ação farmacológica imediata podem ser vantajosamente formulados nestas formas de dosagem. No entanto, a formulação destas formas farmacêuticas exige-lhes resistência mecânica suficiente para suportar os rigores do manuseio e capacidade de desintegrar dentro de alguns segundos em contato com a saliva. O objetivo desta pesquisa foi o de mascarar o gosto amargo de cloridrato de granisetrona. Para mascarar o sabor, utilizou-se Kollicoat smartseal 30D como polímero para io revestimento dos péletes. Os péletes revestidos do fármaco foram diretamente comprimidos com superdesintegrante diferente como Ac-Di-Sol, Explotab e Kollidon CL, em diferentes concentrações 5.0-7.5\% m/m em comprimidos de dispersão oral (ODT). Os comprimidos preparados foram avaliados quanto à dureza, friabilidade, variação de peso, ao tempo de umedecimento, à razão de absorção de umidade, ao tempo de desintegração in vitro e em estudos de dissolução in vitro. Os comprimidos apresentaram características de desintegração rápida com Kollidon CL, em concentração de $7,5 \% \mathrm{~m} / \mathrm{m}$, ou seja, dentro de 20 segundos, o que é característico para formas farmacêuticas de desintegração oral. Mais do que $98 \%$ do fármaco foi liberado a partir das formulações no prazo de 15 minutos. Formulações submetidas a testes de estabilidade de acordo com as diretrizes

"Correspondence: J. G. Avari. Department of Pharmaceutical Sciences. RTM

Nagpur University. Nagpur - 33. India. E-mail: jasminegavari@gmail.com 
da ICH por 3 meses indicaram estabilidade sem alteração no sabor, dureza, teor de fármaco, tempo de desintegração e perfis de dissolução. Assim, os resultados demonstraram que o mascaramento de gosto foi bem-sucedido e atingiu-se rápida desintegração das formas de dosagem na cavidade oral.

Unitermos: Cloridrato granisetrona/mascaramento de sabor. Comprimidos de Dispersão Oral. Grânulos/ revestimento. Medicamentos de via oral/sistemas de administração.

\section{INTRODUCTION}

Orally disintegrating tablets also called as fast dissolving or mouth dissolving tablets are such kind of dosage forms which when placed in mouth disintegrate rapidly in a matter of seconds. They are different from lozenges or buccal tablets which require more than a minute to get dissolved in mouth (William, Tapash, 2005). Any dosage form or a novel drug delivery system which improves patient compliance is of great interest to scientists in which orally disintegrating tablets stands first among them. Market studies indicated that $70 \%$ of the population ask their doctors or prefer to purchase orally disintegrating tablets over conventional tablets or liquids (William, Tapash, 2005). They are more advantageous in case of geriatric or paediatric patients who feel difficulty in swallowing tablets or capsules. They are also useful in disease conditions like motion sickness, repeated emesis or coughing where it is difficult to swallow tablet (William, Tapash, 2005). A vast variety of pharmaceutical research is directed at developing new dosage forms. Most of these efforts have focused on either formulating novel drug delivery systems or increasing the patient compliance. Among the dosage forms developed for facilitating ease of medication, the orally disintegrating systems have been the favorite of product development scientists.

The strategy of compressing multiparticulates into an orally disintegrating tablet is of more interest due to its ease in technology and cost effectiveness. Taste masking is of prime importance in formulating an orally disintegrating tablet. One of the applications of coating of multiparticulate is taste masking (Honey et al., 2008). Multiparticulate or pellets can be compressed into a tablet that can disintegrate in less than a minute (Honey et al., 2008). The concept of orally disintegrating dosage forms has emerged from the desire to provide patients with more conventional means of taking their medication. Interestingly, the demand for ODT has enormously increased during the last decade, particularly for geriatric and paediatric patients who experience difficulty in swallowing conventional tablets and capsules. Hence, they do not comply with prescription, which results in high incidence of ineffective therapy (Seager, 1998). In disease conditions such as motion sickness, sudden episodes of attacks of coughing and repeated emesis swallowing conventional tablets become difficult. Orally disintegrating dosage forms can serve as an effective alternative mode of drug delivery in such situations. When put in the mouth, these dosage forms disintegrate instantly to release the drug, which dissolves or disperses in the saliva. Thereafter, the drug may get absorbed from the pharynx and oesophagus or from other sections of gastrointestinal tract as the saliva travels down. In such cases, bioavailability is significantly greater than that observed from conventional tablet dosage form (Dobetti, 2001, Ghosh, 2005). Hence, orally disintegrating systems may be anticipated to result in achievement of the required peak plasma concentration rapidly for drugs unstable in the gastric $\mathrm{pH}$.

Taste is a perception on which lies the fate of oral pharmaceuticals. Administration of bitter drugs orally with acceptable level of palatability is a key issue for health care providers, especially for paediatric patients (Patel, Prajapati, Raval, 2010). Though adults might think that bitter tasting medicine work better, this is not the case for children (Matsui, 2007). Children might refuse to take their medication completely due to taste issues (Shishu, Kashyap, 2008). Pharmaceutical manufacturers of pediatric medicine need to be aware of children's taste preferences, as the product taste will greatly affect the child's willingness to take the medication repeatedly. Various chemical and physical methods are involved in taste masking, which prevent the drug substance from interacting with taste buds. The simplest method involves use of flavour enhancers (Reddy et al., 2010). A well-constructed flavour system is crucial to mask or hide any medicinal tastes for oral drug formulations, because it influences patient acceptability and compliance and thereby makes the product more tolerable. Children generally prefer sweet preparations with fruity flavours. Flavouring agents are generally present in amounts of from about 0.01 to about $5 \%$. Examples of suitable flavouring agents include cherry flavour, orange-lemon flavour, strawberry flavour, chocolate, peppermint oil, double distilled eucalyptol, anethol, methyl salicylate, oil cassia (Gavaskar et al., 2010). In addition to the flavouring agents, sweetening agents may also be added to provide an acceptable taste. Suitable sweetening agents 
include sucrose, fructose, glucose, sodium saccharin, aspartame (Sharma, Lewis, 2010). Colour is a vital means of identification for many pharmaceutical tablets and is also usually important for consumer acceptance (Saroha et al, 2010).

The recent approaches for taste masking are:

1) Reduction of drug solubility in saliva, where a balance between reduced solubility and bioavailability must be achieved.

2) To alter the ability of the drug to interact with taste receptor (Jha, Sharma, Surendra, 2008).

\section{MATERIAL AND METHODS}

\section{Material}

Granisetron hydrochloride was received as research sample from Ajanta Pharma Pvt. Ltd, Mumbai, India. Kollicoat ${ }^{\circledR}$ Smartseal $30 \mathrm{D}$ and Kollidon CL (crospovidone) procured from BASF India Ltd. Mumbai, India. Croscarmellose sodium (Ac-Di-Sol) by FMC India Ltd. Banglore, India. Avicel PH 101(Microcrystalline cellulose) was supplied by Signet Chemical Corporation Pvt. Ltd., Mumbai, India. Aerosil 200 and Magnesium stearate were obtained by Evonik Degussa India Pvt. Ltd., Mumbai, India and Loba Chemie Pvt. Ltd., Mumbai, India respectively. All other chemicals were of analytical grade and were used as received.

\section{METHODS}

\section{Preliminary studies on screening of plasticizer}

Tri ethyl citrate, Polyethylene Glycol 400 (PEG 400), Propylene Glycol (PG) and Dibutyl Phthalate (DBP) are used as a plasticizer in the concentration range $5-70 \%, 5-30 \%, 5-40 \%$ and $5-50 \%$ respectively in order to study their effect on the tensile strength, $\%$ elongation and folding endurance of matrix type patch prepared by using single polymer.

\section{Physical evaluations of patches}

\section{Thickness}

The thickness of prepared patches was measured using digital vernier callipus with least count $0.01 \mathrm{~mm}$ (Mitutoyo, Japan) at three different places and the mean value was calculated.

\section{Tensile strength}

The instrument was designed such that it had horizontal wooden platform with fixed scale and attachments for two clips that holds transdermal patch under test. Out of the two clips one was fixed and other was movable. Weights were hanged to one end of pulley and the other end of pulley was attached with movable clip. The wooden platform was fitted such that it would not dislocate while the test is running. Three strips of patch were cut having $2 \mathrm{~cm}$ length and $2 \mathrm{~cm}$ width. The thickness and breadth of strips were noted at three sites and average value was taken for calculation. The rate of change of stress was kept constant with the increment of $0.5 \mathrm{~g}$ per 2 minutes. The elongation was observed and the total load was used for calculation.

The tensile strength was calculated by using following formula:

Tensile Stress $(\mathrm{S})=$ Applied force/Cross sectional area $=$ $\mathrm{m} \times \mathrm{g} / \mathrm{b} \times \mathrm{t}$

where $\mathrm{S}=$ tensile strength in $\mathrm{Kg} / \mathrm{mm}^{2} ; \mathrm{m}=$ mass in grams; $\mathrm{g}=$ acceleration due to gravity; $\mathrm{b}=$ width of strip in centimeters; $t=$ thickness of strip in centimeters.

The strain is change resulting in size of strip after the force was applied to its original size. Therefore, the strain can be given as,

Strain $(E)=$ Total Elongation $/$ Original Length $=\mathrm{L}_{-} \mathrm{L}_{0} / \mathrm{L}_{0}$

where $\mathrm{L}=$ length after force was applied; $\mathrm{L} 0=$ original length.

\section{Percent elongation}

The percent elongation at break was measured by formula given below.

Percent Elongation $=$ Total Elongation/Original Length

$$
\times 100=\mathrm{L}-\mathrm{L}_{0} / \mathrm{L}_{0} \times 100
$$

where, $\mathrm{L}=$ length after force was applied.

Weight variation study

For weight variation test, 3 films from each batch were weighed individually and the average weight was calculated. The test was performed to check the uniformity of weight and to avoid batch- to- batch variation.

\section{Folding endurance}

Folding endurance of patches was determined by repeatedly folding a small strip of film $(2 \mathrm{~cm} \times 2 \mathrm{~cm})$ at the same place till it broke. The number of time the film 
could be folded at the same place without breaking was the folding endurance value.

\section{Method of preparation of granisetron pellets}

Granisetron Hydrochloride and other ingredients i.e MCC PH $101(70 \% \mathrm{w} / \mathrm{w})$ and Lactose $(30 \% \mathrm{w} / \mathrm{w})$ were mixed properly in a mortar according to compositions. The resulting mixture or blend was passed through sieve (40\#). This blend was granulate with water as binder to form dump mass which were extrude and spheronise (R \& D Extruder \& Spheronizer, Anish Pharma, Nashik, India) to form pellets of required size.

\section{Coating of pellets with kollicoat smartseal $30 \mathrm{D}$}

Pellets of required size were used for the coating. Kollicoat Smartseal 30D disperse in water along with talc, colorant and plasticizer of required amount on dried basis. The dispersion was allowed to stir for $2 \mathrm{~h}$ obtain a homogeneous dispersion and finally pass through $200 \mu \mathrm{m}$ sieve. The coating dispersion was then layered onto the core pellets in Fluidized bed processor (APCG Series Fluid Bed Processor Anish Pharma, Nashik, India). The coated pellets were further dried in the dryer for $15 \mathrm{~min}$ at $40^{\circ} \mathrm{C}$ after the coating process was finished.

\section{Curing of pellets}

Immediately after the coating process the coated pellets were oven-cured at temperatures $40^{\circ}$ and $65^{\circ} \mathrm{C}$ for the 24 hours. Additionally, samples of coated but uncured pellets were prepared.

\section{Evaluation of pellets}

Prepared pellets were evaluated for different physical parameters like moisture content, drug content, shape, angle of repose, bulk density, tapped density, compressibility index, Hausner ratio. The pellets size was measured under compound microscope (Metzer, India) at 10X magnification for shape determination. Drug content of pellets was determined by U.V spectrophotometer at $244 \mathrm{~nm}$. In-vitro disintegration time was measured by dropping a little quantity of the pellets in a measuring cylinder containing 6 $\mathrm{ml}$ of simulated salivary fluid of $\mathrm{pH}$ 6.8. Moisture content of pellets was measured using halogen moisture analyzer (MB50C, Citizen Scale India Pvt. Ltd., Mumbai, India) at $105^{\circ} \mathrm{C}$. Angle of repose was measured using fixed funnel method. A funnel with $10 \mathrm{~mm}$ inner diameter of stem was fixed at a height of $2.5 \mathrm{~cm}$ over the platform. About $10 \mathrm{~g}$ of sample was slowly passed along the wall of funnel till the tip of the pile formed touches the stem of the funnel. A circle was drawn around the pile base and the radius of cone was measured. Angle of repose was calculated from three averages using formula, $\mathrm{q}=\tan -1$ (Height/Radius). Bulk and tapped density determinations were carried out as per method (Method II) described in United States Pharmacopoeia (USP) 24.

\section{Formulation of granisetron hydrochloride orally dispersible release tablets}

Granisetron Hydrochloride coated pellets and Micro crystalline cellulose (MCC PH 200) were mixed with different disintegrant in a mortar according to compositions given in Table I. The three different disintegrants at varying levels were used for the preparation of ODT tablets. Desired quantity of lubricated blend was weighed and fed manually to a pilot press tablet compression machine (Chamunda Pharma Machinery Pvt. Ltd.) and compressed using $6 \mathrm{~mm}$ flat faced round shaped punches at a weight of $138 \mathrm{mg}$. By direct compression method. Compression force was kept constant for all formulations.

\section{Evaluation of granisetron hydrochloride orally dispersible tablets}

Granisetron Hydrochloride tablets were evaluated for post compression parameters like hardness, weight variation, thickness, friability, disintegration time, drug content and in vitro drug release.

\section{Hardness test}

Tablets require a certain amount of strength or hardness and resistance to withstand mechanical shock of handling in manufacture, packing and shipping. To perform this test tablets were placed between two anvils, force to the anvils and the crushing strength that just causes the tablets to break was recorded. Monsanto hardness tester was used to measure the hardness of tablets. The results were expressed in $\mathrm{kg} / \mathrm{cm}^{2}$.

\section{Thickness}

The thickness of a tablet is only dimensional variable related to the compression process. The thickness of the tablets was determined by the Digital Vernier Caliper instrument. Ten tablets were used for the determination of thickness from each batch. Results were expressed in millimeter (mm). 
TABLE I - Compositions of orally dispersible tablet (138 mg)

\begin{tabular}{llcccccc}
\hline Sr. No. & Ingredients(mg) & $\mathbf{C}_{1}$ & $\mathbf{C}_{2}$ & $\mathbf{C}_{3}$ & $\mathbf{C}_{4}$ & $\mathbf{C}_{5}$ & $\mathbf{C}_{6}$ \\
\hline 1 & Granisetron Hydrochloride & 50 & 50 & 50 & 50 & 50 & 50 \\
2 & MCC PH 200 & 55 & 52.5 & 55 & 52.5 & 55 & 52.5 \\
3 & Sodium starch glycolate & 5.0 & 7.5 & - & - & - & \\
4 & Cross carmellose sodium & - & - & 5.0 & 7.5 & - & - \\
5 & Crospovidon & - & - & - & - & 5.0 & 7.5 \\
6 & Mannitol NF (Pearlitol SD200) & 20.0 & 20.0 & 20.0 & 20.0 & 20.0 & 20.0 \\
7 & Aspartame & 2.0 & 2.0 & 2.0 & 2.0 & 2.0 & 2.0 \\
8 & Peppermint Flavor & 2.5 & 2.5 & 2.5 & 2.5 & 2.5 & 2.5 \\
9 & Magnesium stearate & 1.5 & 1.5 & 1.5 & 1.5 & 1.5 & 1.5 \\
10 & Aerosil (Colloidal silicon dioxide) & 2.0 & 2.0 & 2.0 & 2.0 & 2.0 & 2.0 \\
\hline
\end{tabular}

\section{Friability test}

The friability (\%) of tablets was determined by using Roche type friability testing apparatus. The tablets were subjected to the combined effect of abrasion and shock by utilizing a plastic chamber that revolves at $25 \mathrm{rpm}$, dropping the tablets at a distance of six inch with each revolution. Twenty tablets were weighed and placed in the Roche friability test apparatus. After 100 revolutions, the tablets were dedusted and weighed again. The friability was determined as the percent loss in weight of the tablets.

$$
\text { Friability (5) =1- } \frac{\begin{array}{c}
\text { Weight of tablets } \\
\text { after } 100 \text { revolutions }
\end{array}}{\text { Initial weight of tablets }} \times 100
$$

The acceptable $\%$ friability limit of conventional compressed tablet is 0.5 to $1.0 \%$ (USP 2000).

Dispersion time (Bhardwaj et al., 2010)

In vitro dispersion time was measured by dropping a tablet in a $10 \mathrm{ml}$ measuring cylinder containing $6 \mathrm{ml}$ of buffer solution simulating saliva fluid ( $\mathrm{pH}$ 6.8)

Wetting time (Hindustan et al., 2010)

The wetting time of the tablet was measured using simple procedure. Five circular tissue paper of $10 \mathrm{~cm}$ diameter were placed in petridish with $10 \mathrm{~cm}$ diameter. Ten milliliter of water containing eosin a water soluble dye, was added to the petri dish. A tablet was carefully placed on the surface of tissue paper. The time required for water to reach upper surface of tablet was noted as wetting time.
Wetting volume (Hindustan et al., 2010)

The tablet is placed in center of petridish and with the help of $5 \mathrm{~mL}$ pipette distilled water was added drop wise on the tablet. The volume required to completely disintegrate the tablet was noted as wetting volume.

\section{Water absorption ratio (R) (Battu et al., 2007)}

The weight of the tablet prior to placement in the Petri dish was noted (Wb) utilizing a digital balance. The wetted tablet was removed and reweighed (Wa). Water absorption ratio, $\mathrm{R}$, was then determined according to the following equation. Where $\mathrm{Wb}$ and Wa were tablet weights before and after water absorption, respectively.

$$
\mathrm{R}=\frac{(\mathrm{Wb}-\mathrm{Wa})}{\mathrm{Wa}} \times 100
$$

\section{Disintegration test}

Six tablets were selected randomly from each batch for the disintegration test. Disintegration test was performed in purified water using Electro lab Disintegration tester. Disintegration time (DT) was measured for all tablets and expressed as Mean $\pm \mathrm{SD}$.

\section{In vitro drug release study}

The USP type II dissolution apparatus (Electro lab, India) were used for dissolution having media of $\mathrm{pH} 1.2$ $\mathrm{HCl}$ buffer with $900 \mathrm{ml}$ volume and rotation speed of $50 \mathrm{rpm} .10 \mathrm{~mL}$ sample was withdrawn at predetermined time intervals and replaced with same dissolution 
TABLE II - Evaluation of patches prepared by using single polymer containing optimized concentration of different plasticizer

\begin{tabular}{lcccccc}
\hline Sr. No. & Type of Plasticizer & $\begin{array}{c}\text { \% w/w of } \\
\text { Kollicoat } \\
\text { Smartseal 30D }\end{array}$ & $\begin{array}{c}\text { Thickness } \\
(\mathbf{m m})\end{array}$ & $\begin{array}{c}\text { Tensile Strength } \\
\mathbf{K g} / \mathbf{m m}^{\mathbf{2}}\end{array}$ & \% Elongation & $\begin{array}{c}\text { Folding } \\
\text { Endurance } \\
\text { (No. of times) }\end{array}$ \\
\hline 1 & Tri Ethyl Citrate & 20 & 6.0 & 10.8746 & $77.93 \%$ & 259 \\
2 & Di butyl Pthalate & 20 & 6.2 & 11.0652 & $69.26 \%$ & 220 \\
3 & Propylene Glycol & 20 & 6.0 & 10.823 & $68.15 \%$ & 205 \\
4 & Poly ethylene Glycol 400 & 20 & 6.1 & 10.7054 & $65.17 \%$ & 195 \\
\hline
\end{tabular}

media. The withdrawn samples were diluted 100 times, filtered and analyzed by using UV spectrophotometer at $\lambda_{\max } 263 \mathrm{~nm}$ of granisetron hydrochloride. This test was performed on 3 tablets and mean \pm SD was calculated. The amount of drug release was determined using calibration curve.

\section{Taste evaluation study}

The objective of this study is to conduct and evaluate the palatability of granisetron hydrochloride oral disintegrating tablets. Reference product is not available in market for comparison of the taste evaluation study. Total eight formulations were selected for taste evaluation study, six test formulations, one positive control (Placebo for drug) and one is negative control (Placebo for Taste enhancers like aspartame and peppermint flavor). All formulation batches (C1- C6) were randomized. Each randomization order was assigned with sequence code. For this study we have selected five healthy human male volunteers and were assigned volunteer code.

\section{Stability studies}

The stability studies were performed on the optimized formulation batches to check the effect of environmental or storage conditions. Optimized batch C6 was kept in environmental stability chamber (Remi Lab, Bombay) for accelerated stability condition at $40^{\circ} \mathrm{C} \pm 2^{\circ} \mathrm{C}$ temperature and $75 \pm 5 \%$ relative humidity for a period 3 months. The samples were withdrawn at end of 1,2 and 3 months interval and evaluated for physical parameters, drug content and in-vitro drug release

\section{RESULT AND DISCUSSION}

After studying the effect of triethyl citrate, polyethylene glycol 400, propylene glycol and dibutyl phthalate as plasticizers on tensile strength, \% elongation and folding endurance of matrix type patch prepared by casting on mercury base, good results obtained with triethyl citrate with respect to percent elongation as shown in Table II which help the pellet to withstand in stress condition during compression. Also SEM image of the compressed tablet with different plastisizer revel that triethyl citrate having good plasticizing effect shows no rupture under compression as compared to other plastisizer as shown in Figure 1 and 2.

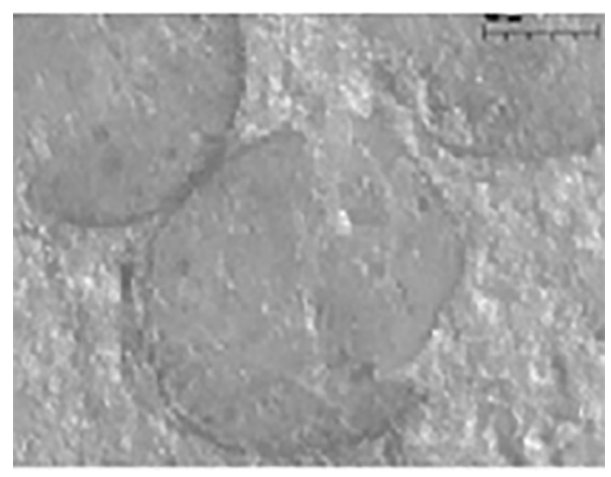

FIGURE 1 - SEM Image of Cross-sections of tablet using PEG 400 as plasticizer.

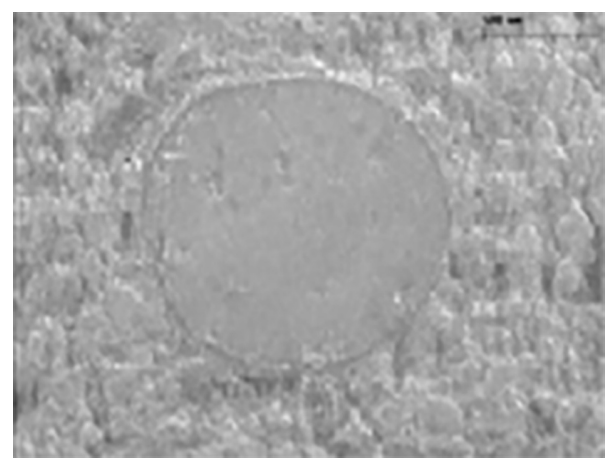

FIGURE 2 - SEM Image of Cross-sections of tablet using TEC as plasticizer.

Angle of repose is less than $30^{\circ}$ suggesting that pellets have good flowability. Bulk density is an indication of packing properties of material. Variations in the bulk density can cause change in fill volume. The bulk density of the pellets depends primarily on particle size 
distribution, particle shape and frequency of particles to adhere together. The particles may pack in such a way so as to leave large gaps between their surfaces resulting in a light powder of low bulk density. On the other hand, the smaller particles may pack between the larger ones to form a heavy powder or one of high bulk density. It has been reported that bulk density less than $1.25 \mathrm{~g} / \mathrm{cm}^{3}$ indicates good flowability. It is evident from table that pellets with all the batches have bulk density in the range 0.3-0.5 g/ $\mathrm{cm}^{3}$. Carr's index (CI) is an important measure that can be obtained from the bulk and tapped densities. The less compressible a material the more flowable it is. Hausner's ratio is the ratio of tapped density and bulk density and is related to interparticle friction and, as such, could be used to predict powder flow properties. Generally a value less than 1.25 indicates good flow properties, which is equivalent to $10 \%$ of Carr's index. When compressibility ranges from 5 to 16 and Hausner's ratio closer to 1.25, the materials have acceptable flow property and packing ability. All pellets have shown good compression properties as shown in Table III.

The compressed tablets were evaluated for weight variation, thickness hardness, friability, disintegration and drug content. All the weights were within $\pm 5 \%$ deviation range and passed the weight variation test according to USP. The hardness of the tablets was found to be about $3.0-4.0 \mathrm{~kg} / \mathrm{cm}^{2}$. Friability index is a measure of integrity of the material, which is a function of cohesiveness. It is an indication of endurance of material during various operations like packaging, transportation and handling. The generally agreed upper limit for friability is $1 \%$. The friability of the tablets was found within the desirable range $0.1-0.3 \%$, hence the tablets passed the friability. Wetting time was determined for all of the formulations. Wetting time of all the formulation was more than $30 \mathrm{sec}$, except C6 $(7.5 \% \mathrm{w} / \mathrm{w})$ having the wetting time $24 \mathrm{sec}$ was less compared to all formulations due to its rapid water absorbing nature involving both capillary and swelling mechanisms of crospovidone. Water absorption ratio ' $R$ ' increased with an increase in superdisintegrants' concentrations from $5-10 \%$. A linear relationship was observed for each of the superdisintegrant types. The increase in ' $R$ ' was most likely due to increased water uptake capacity of the superdisintegrants at higher concentrations. The tablets were assayed and the drug content was found to be in the range of $90-110 \%$ as per USP standards. Disintegration time (DT) stands satisfactory with the time limit of $<1 \mathrm{~min}$ for all the batches, as shown in Table IV. However DT of batch no. C6 found to be $22 \mathrm{sec}$ which was lowest as compared to other formulations. It is considered that the disintegration is the first step in the dissolution of immediate release tablets. The lower the disintegration time, higher the rate of dissolution Hence, for the comparative study, one with the same percentage was selected $(5 \%)$.

TABLE III - Evaluation of Flow properties of coated pellets with Kollicoat ${ }^{\circledR}$ Smartseal 30D D with triethyl citrate as plasticizer (Mean $\pm \mathrm{SD}$ ) (Three number each of $\mathrm{C} 1-\mathrm{C} 6, \mathrm{n}=3$ )

\begin{tabular}{lcccccc}
\hline Test & C1 & C2 & C3 & C4 & C5 & C6 \\
\hline Angle of repose $\left(^{\circ}\right)$ & $26.67 \pm 0.33$ & $29.68 \pm 0.57$ & $27.32 \pm 0.61$ & $27.63 \pm 0.51$ & $26.42 \pm 0.43$ & $28.51 \pm 0.38$ \\
Bulk density $(\mathrm{g} / \mathrm{mL})$ & $0.39 \pm 0.025$ & $0.38 \pm 0.052$ & $0.38 \pm 0.024$ & $0.38 \pm 0.035$ & $0.38 \pm 0.062$ & $0.38 \pm 0.058$ \\
Tapped Density $(\mathrm{g} / \mathrm{ml})$ & $0.44 \pm 0.084$ & $0.44 \pm 0.012$ & $0.44 \pm 0.032$ & $0.44 \pm 0.021$ & $0.44 \pm 0.039$ & $0.44 \pm 0.085$ \\
Carr's index & $11.11 \pm 0.057$ & $11.15 \pm 0.022$ & $11.10 \pm 0.011$ & $11.13 \pm 0.053$ & $11.15 \pm 0.020$ & $11.11 \pm 0.018$ \\
Hausner's ratio & $1.125 \pm 0.034$ & $1.210 \pm 0.043$ & $1.120 \pm 0.010$ & $1.126 \pm 0.008$ & $1.212 \pm 0.034$ & $1.112 \pm 0.031$ \\
\hline
\end{tabular}

TABLE IV - Different evaluation parameters of granisetron hydrochloride ODT tablets (mean $\pm \mathrm{SD}$ ) n=3

\begin{tabular}{lcccccc}
\hline Test & C1 & C2 & C3 & C4 & C5 & C6 \\
\hline Hardness (Kg/cm $\left.{ }^{2}\right)$ & $3.5 \pm 0.5$ & $4.0 \pm 0.5$ & $4.5 \pm 0.5$ & $3.5 \pm 0.5$ & $4.0 \pm 0.5$ & $3.0 \pm 0.5$ \\
Friability (\%) & $0.2 \pm 0.004$ & $0.13 \pm 0.014$ & $0.14 \pm 0.008$ & $0.13 \pm 0.007$ & $0.22 \pm 0.009$ & $0.21 \pm 0.011$ \\
Thickness (mm) & $4.38 \pm 0.40$ & $4.31 \pm 0.45$ & $4.39 \pm 0.25$ & $4.37 \pm 0.48$ & $4.39 \pm 0.14$ & $4.34 \pm 0.64$ \\
Drug content (\%) & $97.24 \pm 0.24$ & $97.36 \pm 0.81$ & $98.20 \pm 0.53$ & $97.52 \pm 0.82$ & $99.20 \pm 0.79$ & $98.62 \pm 0.61$ \\
Weight variation (\%) & $3.75 \pm 0.20$ & $3.26 \pm 0.30$ & $3.49 \pm 0.26$ & $4.56 \pm 0.60$ & $3.48 \pm 0.40$ & $4.64 \pm 0.30$ \\
Disintegration (in sec) & $35 \pm 1.0$ & $30 \pm 1.0$ & $32 \pm 1.0$ & $28 \pm 2.0$ & $28 \pm 1.0$ & $22 \pm 1.0$ \\
Wetting time (in sec) & $37 \pm 1.0$ & $33 \pm 1.0$ & $34 \pm 1.0$ & $31 \pm 1.0$ & $31 \pm 1.0$ & $24 \pm 1.0$ \\
Water absorption ratio & 148 & 178 & 120 & 132 & 95 & 105 \\
\hline
\end{tabular}




\section{In vitro drug release studies of granisetron hydrochloride ODT tablets}

Drug release of C1-C6 batch containing various superdisintegrants in different concentration of 5 and $7.5 \%$ w/w was compared, it was found that C6 batch containing Crospovidon releases drug more promptly and completely within $30 \mathrm{~min}$. Hence, C6 batch is considered as optimized batch for granisetron hydrochloride orodispersible tablets as shown in Figure 3.

The results shown in Table $\mathrm{V}$ indicate that all the prepared formulation were similar in terms of patient acceptability, it was observed in prepared formulations using peppermint flavor, mannitol as a flavor enhancing agent, aspartame as a taste enhancing agents are responsible for good acceptability by the volunteers.

\section{Stability study}

Stability testing on optimized batches of orodispersible tablets as per ICH guidelines was carried out. After checking the parameters, no significant change was found in all the batches before and after stability study. The results obtained as shown in Table VI. The in vitro

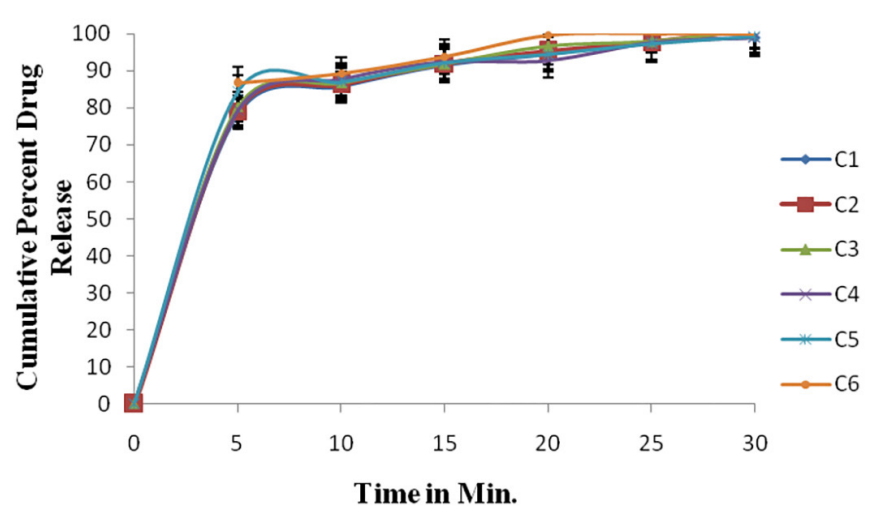

FIGURE 3 - Effect of different Superdisintegrant Sodium starch glycolate $(\mathrm{C} 1 \& \mathrm{C} 2)$, cross carmellose sodium (C3 \& C4) and crospovidone (C5 \& C6)in different concentration ( $5 \%$ \& $7.5 \%)$ on in vitro release of granisetron hydrochloride $(n=3$, mean $\pm S D)$.

drug release study of optimised batch C6 was carried out and no significant changes were found in release patter of drug as shown in Figure 4.

\section{CONCLUSION}

Taste masked orally disintegrating granisetron

TABLE V - Summary report of taste evaluation study report

\begin{tabular}{lccc}
\hline Formulation & Average point by individual & Acceptability & Rank \\
\hline Positive control & 98 & Very Good & 1 \\
C1 & 95 & Very Good & 3 \\
C2 & 91 & Very Good & 6 \\
C3 & 94 & Very Good & 4 \\
C4 & 90 & Very Good & 7 \\
C5 & 97 & Very Good & 2 \\
C6 & 92 & Very Good & 5 \\
Negative control & 11 & Worst & 8 \\
\hline
\end{tabular}

Scale range: 81-100 - Very Good, 71-80 - Good, 61 - 70 - Acceptable, 41-60 - Poor, 11-40 - worst and 0-10 - not tolerable

TABLE VI - Evaluation parameters of stability batch (C6)

\begin{tabular}{lcccc}
\hline Evaluation parameters & $\begin{array}{c}\text { Before stability } \\
\text { storage }\end{array}$ & $\begin{array}{c}\text { After1 month } \\
\text { storage }\end{array}$ & $\begin{array}{c}\text { After2 months } \\
\text { storage }\end{array}$ & $\begin{array}{c}\text { After3 months } \\
\text { storage }\end{array}$ \\
\hline Hardness $\left(\mathrm{kg} / \mathrm{cm}^{2}\right)$ & $3.0 \pm 0.4$ & $3.0 \pm 0.6$ & $2.5 \pm 0.6$ & $2.5 \pm 0.8$ \\
Friability (\%) & $0.21 \pm 0.06$ & $0.23 \pm 0.06$ & $0.26 \pm 0.03$ & $0.26 \pm 0.04$ \\
Weight variation (\%) & $4.64 \pm 0.30$ & $4.67 \pm 0.50$ & $4.70 \pm 0.43$ & $4.69 \pm 0.35$ \\
Drug content (\%) & $98.62 \pm 0.61$ & $97.64 \pm 1.3$ & $96.89 \pm 1.5$ & $96.18 \pm 1.9$ \\
\% drug release of at the end of 30 min & $99.75 \pm 1.5$ & $98.98 \pm 1.4$ & $97.97 \pm 2.2$ & $97.59 \pm 1.9$ \\
\hline
\end{tabular}

The data are presented as mean value \pm S.D. $(n=3)$ 


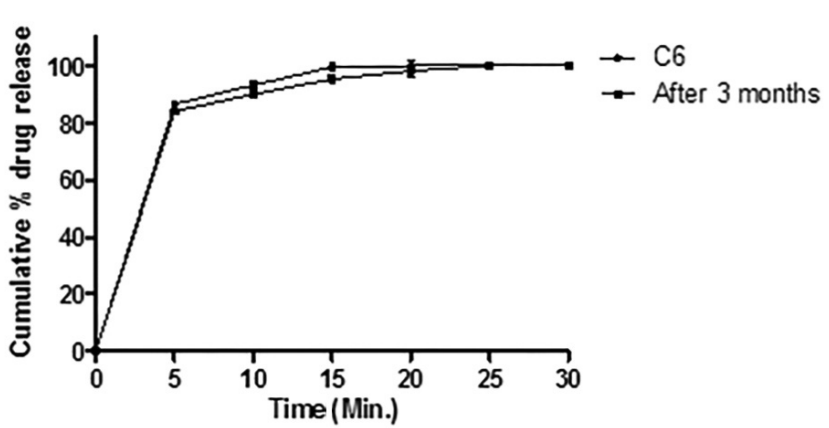

FIGURE 4 - In vitro drug release study of granisetron hydrochloride from ODT tablets before and after 3 month

hydrochloride tablets were formulated for more palatable and compliance disintegration in oral cavity. By using Kollicoat ${ }^{\circledR}$ Smartseal 30D masked effectively bitter taste of granisetron hydrochloride. Triethyl citrate was found to be the best plasticiser having high flexibility with no rupture during compression of pellets. The formulations containing Crospovidon as disintegrant have shown tablets with desired physical parameters and about $93 \%$ of drug was released within 10 minutes when used at $7.5 \% \mathrm{w} / \mathrm{w}$ level. The formulation of Granisetron hydrochloride orally disintegrating tablet was successfully developed with following attributes,

- $\quad$ Rapid Disintegration in mouth

- $\quad$ Desired Dissolution Profile

- $\quad$ Taste mask with smoother mouth feel

- $\quad$ Stable and robust formulation

\section{ACKNOWLEDGEMENT}

Authors would like to thank Ajanta Pharmaceuticals Ltd. (Kandivali Mumbai, India) for providing drug sample. We are also thankful to Head of the Department for providing us with the necessary requirements for the research activity.

\section{REFERENCES}

BATTU, S.K.; REPKA, M.A.; MAJUMDAR, S.; RAO, M.Y. Formulation and evaluation of rapidly disintegrating tablet Fenoverine tablets: effect of superdisintegrants. Drug Dev. Ind. Pharm., v.33, n.11, p.1225-1232, 2007.

BHARDWAJ, S.; VINAY, J.; JAT, R.C.; MANGAL, A.; JAIN, S. Formulation and evalution of fast dissolving tablet of aceclofenac. Int. J. Drug Deliv., v.2, n.1, p.93-97, 2010.
DOBETTI, L. Fast melting tablets: developments and technologies. Pharm. Technol. Drug Deliv., p.44-50, 2001. Available at: <http://images.alfresco.advanstar.com/ alfresco_images/pharma/2014/08/22/e45df9c6-e7d5-45888f1d-94c924c72ff9/article-5137.pdf $>$.

GAVASKAR, B.; KUMAR, S.V.; SHARAN, G.; RAO, Y.M. Overview on fast dissolving films. Int. J. Pharm. Pharm. Sci., v.2, n.3, p.29-33, 2010.

GHOSH, T.K.; PFISTER, W.R. Quick dissolving oral dosage forms: scientific and regulatory considerations from a clinical pharmacology and biopharmaceuticals perspective. In: Drug delivery to the oral cavity: molecules to market. New York: CRC Press, 2005. p.337-356.

HINDUSTAN, A.A.; ANURADHA, C.M.; KUMAR, C.S.; REDDY, K.K.; KUMAR, J.D. Novel approach in formulation and evaluation of mouth dissolving tablets of ondansetorn hydrochloride. Int. J. Appl. Biol. Pharm. Tech., v.2, n. 1, p.582-588, 2010.

HONEY, G.; PARSHURAM, R.; VIKAS, R.; ASHOK, T. Orally disintegrating systems: innovations in formulation and technology recent patents. Drug Deliv. Formul., v.2, n.3, p.258-274, 2008.

JHA, S.K.; SHARMA, U.R.; SURENDRA, V. Taste masking in pharmaceuticals: an update. J. Pharm. Res., v.1, n.2, p.126-130, 2008.

MATSUI, D. Assessing the palatability of medications in children. Paediatr. Perinat. Drug Ther., v.8, n.2, p.55-60, 2007.

PATEL, A.R.; PRAJAPATI, D.S.; RAVAL, J.A. Fast dissolving films (Fdfs) as a newer venture in fast dissolving dosage forms. Int. J. Drug Dev. Res., v.2, n.2, p.232-234, 2010.

REDDY, V.R.S.; DONDETI, S.; MANAVALAN, R.; SREEKANTH, J. Palatability evaluation study of oral disintegrating tablets by Human. Int. J. Pharm. Sci. Res., v.1, n.8, p.326-346, 2010.

SAROHA, K.; MATHUR, P.; VERMA, S.; SYAN, N.; KUMAR, A. Mouth dissolving tablets: an overview on future compaction in oral formulation technologies. Pelagia research library. Pharmacia Sinica, v.1, n.1, p.17987, 2010. 
SEAGER, H. Drug delivery products and the Zydis fastdissolving dosage form. J. Pharm. Pharmacol., v.50, n.4, p.375-382, 1998.

SHARMA, S.; LEWIS, S. Taste masking technologies: a review. Int. J. Pharm. Pharm. Sci., v.2, n.2, p.6-13, 2010.
SHISHU, N.; KASHYAP, N. Taste-masking and development of pediatric formulation of nalidixic acid. The IUP $J$. Chem., v.11, n.2, p.39-45, 2008.

WILLIAM, R.P.; TAPASH, K.G. Orally disintegrating tablets. Pharm. Technol., 2005.

Received for publication on $08^{\text {th }}$ June 2014 Accepted for publication on $17^{\text {th }}$ June 2015 